\title{
DE RAADSELACHTIGE TOESPRAAK VAN DEN HINDOE-BARD IN DE MALEISCHE KRONIEKEN
}

DOOR

\author{
DR. PH. S. VAN RONKEL.
}

In het voorafgaand artikel van den heer Rouffaer (bl. 31) is sprake van eene in de meeste teksten van de Maleische Kroniek Sadjarah Melajoe voorkomende Hindoesche toespraak van de mythische persoon Baț, die raadselachtige woorden sprak, en de stamvader werd van hen die de oude overleveringen kenden, die dus zijn naam (het Sanskrit bhațța, de geleerde, de bard) niet ten onrechte droeg. Niet in alle uitgaven is die toespraak opgenomen, doch in de Engelsche vertaling Malay Annals van John Leyden staat de rede in Sanskrit-letters. Straks zullen wij zien dat bedoelde zaak wel hier en daar is vermeld; laat ons erkennen dat hiervan geen bericht is gegeven in onze beschrijving der Haagsche en Bataviasche handschriftenverzamelingen, waar de bedoelde passus in verschillende lezingen is afgedrukt.

In de eerste der door den heer Rouffaer aangewezen plaatsen luidt de vertaling: .... a man named Bat'h, with an immense turban, who immediately stood up, and began to recite the praises of Sangsapurba (which he does very ingeniously in the Sanscrit language). In de noot volgt de tekst, die op Sanskrit gelijkt, maar zulks niet is, noch in het schrift, noch in de taal.

In de tweede der aangewezen plaatsen worden ceremoniën vermeld waarbij the hereditary minstrels, or descendants, of Bat'h shall recite the king's titles from the cherei, according to the regular formulary; ook hier wordt in eene noot de inlandsche, soi-disant Sanskrit, tekst gegeven, die nagenoeg gelijkluidend is met dien van den eersten locus. 
Naar aanleiding van Rouffaers opmerkingen zij het ons vergund mede te deelen: vooreerst dat de passage geen Sanskrit is, ten tweede dat over de bedoelde formule, de cherei of chiri (tjiri) een vrij groote literatuur bestaat.

Het schrift is geen Sanskrit (Nagari), doch Bengaalsch, wat op zich zelf niets beduidt, daar in de eerste decaden der vorige eeuw Sanskrit-werken in Bengalen werden uitgegeven, met hulp van Bengaleezen, in Bengaalsch type.

Prof. J. Ph. Vogel had de goedheid den passus voor mij in Sanskrit-letters te transcribeeren, en deed mij opmerken dat er wel enkele Sanskrit-woorden in te herkennen zijn, doch dat het geheel hopeloos corrupt is. Uit Prof. Vogel's Sanskrit-transcriptie, waarin op enkele onduidelijke ligaturen na, alles is terechtgebracht, brengen wij de beide plaatsen in Latijnsch schrift over (zie de noot op deze bladzijde) ter eventueele vergelijking met den tekst in Arabisch schrift, gelijk die in de genoemde handschriftencatalogi is vermeld, en met de overzichten in de straks te noemen werken.

De formule nu wordt cherai of chiri, d.i. tjiri, genoemd, welk woord óf het Sanskrit carya, wat gedaan moet worden, ceremonieel, of het Minangkabausche, ook in het Javaansch bekende, woord $\mathrm{tjiri}=$ teeken, merkteeken zou kunnen zijn.

Dien term vindt men in het opschrift van een aan deze quaestie gewijd artikel in deel XIII van het Journal of the Royal Asiatic Society (1881) van W. E. Maxwell: An account of the Malay "chiri,» a Sanscrit Formula. Over den tjiri nu licht de schrijver ons aldus in: Mohamedans by religion, and acquainted with no written character but that of the Arabs, a Sanskrit invocation in use among the Malays would appear an

Transscriptie der beide formulieren:

p. 24.

âhâ swasti yâhakâ șrîmahârâjakâ swarâ? ṣrâsu punanwa granâha rạ̣abhûmi bhajawana wikramâ namkaranâ mukuḍarama hatha tribha waha sparthakûṇ̣a? | winâjańka dharmmabâhu yata srarana bitarana bitarana simbâsanawana wikramâ wanârṇa wanâwika sadayânu dewa wiha | yarawâdi kânamûnamûnî mânika bhîdharmagajâdhirâ râ parametharaka

p. 100.

âhâ șuguta yâhakâ bhîmahârâja bhîmata bhîdubhapraswarṇabhûmi bhajapâna wikramâha - naka karnabhu raṇamutha tribhawanasparṣa șașkita wihânaka dharmmârabheșikuna simhâsana ranawikrama wânarânata panâdhi. tawanâdhika sadayârdra daya dewa dayn paradayakâna maunimânamânik ya șrîdharmmarâjâdhirâja pareșwarî yâwajjî̀am. 
absolute anachronism. Yet this is what the Malay chiri seems to be. Perfectly unintelligible to the people who have handed it down for generations by oral repetition. and in Mohamedan times by means of the Arabic character, and much corrupted in consequence, it seems, nevertheless, capable of identification as an address of praise, either to a Hindu god or to a Hindu king.

Daarna volgt de tekst van den tjiri die in Perak wordt (of werd) voorgelezen bij de installatie van inlandsche chef's; de erfelijke voordragers behooren tot de bangsa moentah le mboe, blijkbaar in verband met de in de Sadjarah Melajoe vermelde mythe van het uitbraaksel der koe, waaruit de bard Bat geboren werd.

$\mathrm{Nu}$ volgt een dergelijke tjiri uit Broenai, die daar eveneens bij de ambtsaanvaarding van inheemsche (en Chineesche) hoofden gereciteerd werd; opgemerkt wordt: that it differs very much from the Perak version, though some of the words are identical, or nearly so. Na deze uiteenzetting geeft Maxwell verslag van de legende van Baț, den uit het door het rund gebraakte schuim ontsproten bard, den stamvader van hen die den tjiri reciteeren van oude tijden af. Uit vier handschriften wordt voorts de tekst medegedeeld, met vermelding der afwijkingen in de lezing, maar bij de tweede maal dat de tjiri in de Maleische Kroniek wordt vermeld - the organization (of the ceremonial of the court of a Malay Raja) attributed by the chronicler to the first Mohamedan Raja of Malacca, but evidently of Hindu origin - bepaalt de schrijver zich tot de vertaling van den betrokken passus over den chiri "read in the presence of the Raja by one of the posterity of Bhaț.»

De interne evidentie der legende wordt nu behandeld in verband met analoga in Hindoestan. Daar is bhat de gewone naam voor "a bard or encomiast, en in Goedzerat - naar men weet het land vanwaar de kooplieden-islaminvoerders in den Maleischen Archipel kwamen - is het de benaming van een bepaalden stam die claiming a semi-divine origin, exercised in former days the very functions ascribed by the Malay annalist to the Bhat of his story, namely, the recitation of laudatory verses and the compilation of genealogies».

De "Bhawt's» en hun verwanten de "Charun's» zijn de zangers, auguren en toovenaars; de laatsten beweren ontstaan te zijn uit het voorhoofdzweet van Mahâdewa, die den stamvader van Dl. 77 
hun geslacht belastte met de zorg voor zijn rund, de lemboe der Maleische mythe, de legende waarin Bat tweemaal optreedt als huwelijkssluiter (de twee Palembangsche vrouwen met de gezellen van Sri Triboewana en den radja met de vorstin Wan Soendari), evenals de Goedzeratsche Bhaț's de huwelijken registreeren en verwantschapsquaesties beslissen bij hunne Rajpoetsche vorstelijke cliënten.

In geheel Zuid-Indie is bart-baut-batt de naam van de hofbards, die zeer bedreven zijn in "speaking improvisatore of any subject proposed to them, a declamation in measures wich may be considered as a sort of medium between blank verse and modulated prose.»

Aan het slot van het opstel wijst de auteur op de mogelijkheid dat de "chiri" oorspronkelijk een fragment is van een lofzang op Çiva den grooten Hindoe-god, en vermeldt in kort overzicht de punten van zijn onderzoek; hij wilde echter zijn "paper. niet besluiten zonder melding te maken van Leyden's poging "to give an intelligible rendering in Sanskrit of the corrupted Malay version., Wij halen zijn woorden aan, daar ze de zaak nader critisch toelichten.

"Unfortunately we have no clue to the Malay manuscript from which Leyden made his translation, and there is noting to show how far his version in the Sanskrit character corresponds with the Malay original. Dr. Rost. who has examined it, pronounces it to agree but little with the only versions of the formula to which we have access. It was not printed until ten years after the death of Dr. Leyden in Java, and has probably suffered for want of revision by him. Neither M. Dulaurier, who edited the text of a portion of the "Sajarah Malayu, nor M. Devic, who has recently published a translation of Dulaurier's text, has noticed the subject at all.»

Hieraan voegen wij voor de volledigheid nog eene aanhaling toe, en wel uit Shakespear's Hindoêstânî-woordenboek s. v. mâgadh: a bard, a minstrel whose duty it is to recite the praises of sovereigns, their genealogy and the deeds of their ancesters, in their presence; and to attend on the march of an army, and animate the soldiers by martial songs. The minstrels form a particular cast, said to spring from a Vaisya father and Kṣatriya mother: in mythology, they are said te have been created at once by the will of Siva. Under the name of 
Bhāțs, they are still numerous in some parts of India, especially Gujarāt, where they are a privileged tribe.

Evenals zoo menig gegeven van dien aard - men zie slechts de opgaven in Dr. Schrieke's proefschrift - wijst dus ook de naam Bat naar den oorsprong van indonisischen islam en populair geloof: den handelsweg uit Goedzerat!

Ook in het Drâvidische Zuid-Indië vond het Sanskrit bhațța zijn weg, en ook daar werd de beteekenis gespecialiseerd: patțan (getenuïseerde aanvangsklank en masc. uitgang a ṇ) $=$ savant, titre honorifique d'une classe de brames, chanteur, sage.

Trouwens die eigenaardige beteekenis kent het Sanskrit reeds eenigermate, immers bhatța is niet alleen: geleerde, maar ook de naam van "eine mit Lobreden sich beschäftigende Mischlingskaste». De vraag doet zich voor of de naam Bat der Maleische legende wel iets uit te staan heeft met $b$ hatta $=$ geleerde, en niet uitsluitend met den naam der mengkaste in verband gebracht moet worden, om 't even of die naam oorspronkelijk identisch is met het nomen substantivum bhațta.

Immers Bhat kan tweeërlei zijn: $1^{\circ} \mathrm{bhattt} \mathrm{of} \mathrm{bhuțț,}$ Hindî bh at, Sanskrit Bhațța «learned Brahman, also the name of a particular tribe of Brahmans in Benares, said to have sprung from a Maratha father and a mother of the Sarwario tribe of Brahmans," en $2^{\circ}$ bhaț, Hind. bhât, niet het Sanskrit $\mathrm{bhattca,} \mathrm{maar} \mathrm{bhața} \mathrm{als} \mathrm{wijziging} \mathrm{van} \mathrm{bhârata,} \mathrm{nakomeling}$ van Bharata, voorts: bard, herald, genealogist, verdeeld in: Birm-bhat (hired on particular occasions te recite the traditions of a family). en Djaga-bhat (the chroniclers of the family by heridatery descent, and visiting the members periodically, to take note of all occurences regarding them). H. H. Wilson, aan wien beide citaten ontleend zijn, voegt hierbij: both classes are as much dreaded for their reputed sanctity..... Some have become converts to Mohammedanism.

Over Bat is genoeg gezegd; de hoofdzaak is de vermelding der literatuur over den passus en de daar bedoelde zaak.

$\mathrm{Er}$ is namelijk nog meer te vermelden dan Maxwell's artikel in genoemd tijdschrift, en wel een stukje van denzelfden auteur in deel X (1883) van het Journal of the Straits Branch of the Royal Asiatic Society, bl. 287-289, getiteld The Chiri.

*In a paper contributed to the Journal of the Royal Asiatic Society in 1880 (lees 1881), I gave an account », zoo begint de 
schrijver, "of the Chiri, an unintelligible formula recited in Malay courts at the installation of Chiefs, and the versions in use in Perak and Brunei were compared with that which is to be found in the Sajarah Malayu.,

Te Colombo toonde Maxwell de drie teksten aan J. A. Swettenham, die ze aan het oordeel van een met Pali bekenden pandit onderwierp. Eerst geeft de auteur de lezing met de critische noten uit zijn vroeger artikel, dan de transcriptie, en daarna de Pali-lezing, zooals de Singaleesche deskundige die voorstelde.

Eindelijk volgt de vertaling van den would-be Pali-passus.

Maar... de onverstaanbare tekst is geen Pali. Men behoeft geen paliloog te zijn om te weten dat de Sanskrit-woorden in den tjiri Sanskritiseerend, niet Prâkritiseerend, en dus niet Pali zijn. De "Pandit» heeft zijn fantasie laten gelden, en zijn ondervrager afgescheept met schijn-wijsheid, evenals eenige tientallen jaren te voren de "geleerde» zegsman van Leyden dezen "hielp" aan den Sanskrit-tekst dien hij vroeg.

En de zoogenaamde vertaling? Dr. Rost, zoo besluit het artikel, says: "the unriddling of the Chiri by the Pandit in Ceylon is certainly very ingenious, and at any rate competes favourably with all others yet attempted.»

Meer was er blijkbaar niet van te zeggen,, en dat weinige was nog te veel.

$\mathrm{Na}$ dit kleine artikel is er over Bat en tjiri nog iets geschreven - behalve in handschriften-catalogi, en in Rouffaer's stuk, waarin verwezen wordt naar de gelijkstelling Baț-Bhațta (in Tijdschrift T. L. \& Vk. v. N. I. deel LVII), welke vergelijking uit de voorgaande bladzijden eenige toelichting kan erlangen en wel in de $2^{e}$ ed. van R. J. Wilkinson's History of the Peninsular Malay's (Papers on Malay subjects, Singapore 1921), bl. 20, waar medegedeeld wordt, dat het hoofd van Pérak is - the hereditary custodian of the ancient proclamation in a forgotten tongue by which the herald installed Sang Sapurba as ruler of the Palembang world. That form of proclamation (the chiri) is still used, with many old-world ceremonies) at the installation of every Perak Sultan and of all his high officers of state,»

Op bl. 22 wordt nog eens de tjiri vermeld, nl. ‘ the coronation formula is in either Sanskrit or Pali; it suffers from having been transcribed into Arabic characters that are ill adapted for 
representing sounds. Its text - so far as it can be interpreted reveals nothing.»

Inderdaad, de tekst openbaart ons niets. Vast staat echter dat wat er in voorkomt geen Sanskrit is. De meening dat Bat uit de Maleische Kronieken Sanskrit kon spreken is dus volstrekt niet bewezen, zoodat die veronderstelling van Rouffaer (bl. 31 r. 5) mitsgaders zijne aanroeping van Adityawarman n. f. allen grond missen.

N.B. Blijkens S. R. Dalgado's Glossário Luso-Asiático (Coimbra, 1919) is bhat een Portugeesch.Indische term in den vorm bôto en bôtto (bl. 141 s. v.) $=$ geletterde brahmaan, hindoe-priester; de vorm zou een lusitanisme zijn van het Concani bhat, d. i. het Sanskrit bhatta. Na een reeks van Portugeesche citaten, aanvangende met 1587, vermeldt de auteur een Engelschen locus uit Fryer, East India II, p. 101, weer sprake is van butts, die zich wijden "to an exact regular life, abstracted from all worldly employments". 